\title{
ANALISIS PERILAKU KETERATURAN MENGKONSUMSI TABLET TAMBAH DARAH DENGAN KEJADIAN ANEMIA PADA IBU HAMIL
}

\author{
Yusro Paridah $^{1}$, Rico Januar Sitorus ${ }^{2}$, Rostika Flora ${ }^{3}$, \\ Nurlaili ${ }^{4}$, Risnawati Tanjung ${ }^{5}$ \\ Universitas Sriwijaya ${ }^{1,2,3}$ \\ Universitas Bengkulu ${ }^{4}$ \\ Politeknik Kesehatan Kementerian Kesehatan Medan ${ }^{5}$ \\ yusroparida87@gmail.com ${ }^{1}$
}

\begin{abstract}
ABSTRAK
Penelitian ini bertujuan untuk menganalisis hubungan perilaku mengkonsumsi tablet tambah darah dengan kejadian anemia pada ibu hamil di Kabupaten Kepahiang. Rancangan penelitian yang digunakan dalam penelitian ini adalah analitik kuantitatif dengan desain potong lintang (cross-sectional). Hasil penelitian menunjukkan bahwa sebagian besar responden atau sebanyak 56 orang $(55,4 \%)$ memiliki sikap positif terhadap kejadian anemia, sebagian besar atau sebanyak 61 orang $(60,4 \%)$ memiliki perilaku tidak teratur dalam mengkonsumsi tablet tambah darah, hasil pengukuran kadar $\mathrm{Hb}$ menunjukkan hampir seluruhnya atau sebanyak 82 orang $(81,2 \%)$ mengalami anemia, keteraturan konsumsi tablet tambah darah dengan kejadiaan anemia menunjukkan dari 61 orang responden yang tidak teratur mengkonsumsi tablet tambah darah hampir keseluruhan atau sebanyak 60 orang responden $(98,4 \%)$ mengalami kejadian anemia. Simpulan, ada hubungan antara prilaku mengkonsumsi tablet tambah darah dengan kejadian anemia pada ibu hamil.
\end{abstract}

Kata Kunci: Anemia, Ibu Hamil, Tablet Tambah Darah

\begin{abstract}
This study aims to analyze the relationship between consuming blood-added tablets and anemia in pregnant women in the Kepahiang District. The research design used in this study was quantitative analytic with a cross-sectional design. The results showed that most or as many as 56 people (55.4\%) had a positive attitude towards the incidence of anemia. As many as 61 people (60.4\%) had irregularly consumed blood-added tablets. Almost entirely or as many as 82 people $(81.2 \%)$ experienced anemia, regular consumption of blood-added pills with anemia showed that 61 respondents who did not regularly consume blood tablets in total or as many as 60 respondents (98.4\%) experienced anemia. In conclusion, there is a relationship between consuming blood-added pills with the incidence of anemia in pregnant women.
\end{abstract}

Keywords: Anemia, Pregnant Women, Blood Add Tablets 


\section{PENDAHULUAN}

Kematian maternal merupakan masalah global dalam kesehatan yang menjadi indikator dalam keberhasilan program kesehatan ibu sekaligus salah satu indikator dalam menggambarkan derajat kesehatan masyarakat. World Health Organization (WHO) tahun 2017 memperkirakan setiap harinya 800 perempuan meninggal akibat komplikasi kehamilan dan proses melahirkan. Data WHO menyebutkan bahwa kematian ibu di negara berkembang disebabkan oleh anemia dalam kehamilan 40\%, eklampsia 34\%, karena penyakit 26\%, dan infeksi 12\% (Andini, 2020).

Laporan data menurut WHO tahun 2018 anemia dalam kehamilan merupakan masalah kesehatan yang utama di negara berkembang dengan tingkat kematian yang tinggi dalam kehamilan. Total penderita anemia pada ibu hamil di Indonesia adalah 70\%, artinya dari 10 ibu hamil, sebanyak 7 orang akan menderita anemia. Anemia adalah suatu keadaan dimana kada Hemoglobin $(\mathrm{Hb})$ dalam darah lebih rendah dari normal untuk kelompok orang menurut umur dan jenis kelamin, pada wanita usia remaja hemoglobin normal adalah 12-15 g/dl, dan pada pria remaja hemoglobin 13-17 g/dl (Ramadhaniati et al., 2020). Hal ini ditunjukkan dengan masuknya anemia ke dalam daftar Global Burden of Disease 2004 dengan jumlah penderita sebanyak 1,159 miliar orang di seluruh dunia (sekitar 25\% dari jumlah penduduk dunia). Sekitar 50\% dari semua penderita anemia mengalami defisiensi besi (Mairita et al., 2018).

Secara global angka prevalensi anemia masih sangat tinggi prevalensi anemia pada ibu hamil di seluruh dunia adalah sebesar 43,9\%. Prevalensi anemia pada ibu hamil diperkirakan di Asia sebesar 49,4\%, Afrika 59,1\%, Amerika 28,1\% dan Eropa 26,1\%. Angka kejadian anemia di Indonesia terbilang masih cukup tinggi. Menurut data Riskesdas 2018 menyatakan bahwa di Indonesia sebesar 48,9\% ibu hamil mengalami anemia dan sebanyak 84,6\% anemia pada ibu hamil terjadi pada kelompok umur 15-24 tahun.

Provinsi Bengkulu adalah salah satu provinsi yang berada di Inonesia yang memiliki angka kejadian anemia yang terus meningkat setiap tahunnya. Berdasarkan data Dinas Kesehatan Provinsi Bengkulu jumlah kejadian anemia tahun 2017 berjumlah 4030 kasus dari $40671 \mathrm{ibu}$ hamil atau sebesar 10\%. Kejadian ini berada di Kabupaten Seluma sebanyak 946 kasus, di Kota Bengkulu sebanyak 843 kasus dan di Kabupaten Muko-Muko sebanyak 680 kasus (Dinkes Provinsi Bengkulu, 2019). Sedangkan dari data Dinkes Provinsi Bengkulu tahun 2019 di Kabupaten Kepahiang kasus anemia pada ibu hamil sebanyak 424 kasus (Dinkes Kepahiang, 2019).

Kabupaten Kapahiyang terletak di Provinsi Bengkulu, memiliki kasus anemia yang tinggi pada tahun 2019 sebesar 424 ibu hamil dengan anemia yang terdiri dari 420 orang yang memiliki $\mathrm{Hb}<8 \mathrm{mmHg}$. Pada tahun 2020 menunjukan terdapat 334 ibu hamil dengan anemia yang terdiri dari 327 orang $\mathrm{Hb} 8-11 \mathrm{mmHg}$, dan 7 orang $\mathrm{Hb} 8 \mathrm{mmHg}$ sedangkan pada tahun 2021 tercatat pada bulan Januari - Maret tercatat 108 kasus ibu hamil yang mengalami anemia yang terdiri dari 80 orang $\mathrm{Hb}-8-11 \mathrm{mmHg}$ pada trimester 1,21 orang $\mathrm{Hb} 8-11 \mathrm{mmHg}$ trimester II dan 3 rang dengan $\mathrm{Hb} 8 \mathrm{mmHg}$. jumlah kasus anemia pada ibu hamil sebesar 16,3\%. Dari data di atas, Puskesmas yang memiliki data anemia paling tinggi yaitu Puskesmas Kebawetan yaitu sebesar 83,8\% (Dinkes Kepahiang, 2019).

Kebanyakan anemia dalam kehamilan disebabkan oleh defisiensi besi. Saat ibu hamil terkena anemia defisiensi zat besi, hal inilah yang dapat mempengaruhi beberapa faktor kesehatan salah satunya adalah pertumbuhan dan perkembangan janin/bayi saat kehamilan maupun setelahnya. Anemia pada ibu hamil dapat meningkatkan risiko kelahiran prematur, pendarahan, kematian ibu dan anak, berat bayi lahir rendah, serta penyakit infeksi. Anemia defisiensi besi pada ibu dapat mempengaruhi pertumbuhan dan perkembangan janin/bayi 
saat kehamilan maupun setelahnya. Berdasarkan penelitian Sulfianti (2021) juga menyatakan bahwa umur ibu berhubungan dengan kejadian anemia. Hasil penelitian Irwan \& Rahmat (2018) juga menyatakan terdapat hubungan umur ibu dengan kejadian ibu hamil. Pada penelitian Musni (2019) umur ibu kurang dari 20 tahun dan lebih dari 35 tahun ketika masa kehamilan 3,94 kali lebih beresiko terkena anemia.

Mengingat bahaya dampak yang ditimbulkan akibat anemia dapat menyebabkan kematian ibu dan anak, meningkatkan kelahiran premature serta penyakir infeksi maka untuk mencegah anemia setiap ibu hamil diharapkan mendapatkan Tablet Tambah Darah (TTD) minimal 90 tablet selama kehamilan (Kemenkes RI, 2020). Maka dari itu perilaku keteraturan ibu dalam mengkonsumsi Tablet Tambah Darah (TTD) dalam mengobati anemia sangat penting. Rendahnya kesadaran berperilaku dalam mengkonsumsi suplemen besi merupakan salah satu penyebab angka prevalensi anemia masih tetap tinggi. Perilaku keteraturan merupakan hasil dari niat dari ibu hamil usia remaja tersebut untuk mengkonsumsi TTD dengan frekuensi satu tablet setiap minggu sepanjang tahun. TPB atau teori perilaku terencana menyebutkan dimensi yang mempengaruhi terbentuknya niat individu adalah sikap, norma subjektif, dan persepsi kontrol perilaku (Ramdhani \& Ichwanuddin, 2020).

Penelitian terdahulu telah banyak mengupas tentang kejadian anemia pada ibu hamil, namun belum ada yang menganalisis keteraturan mengkonsumsi tablet tambah darah dengan kejadian anemia pada ibu hamil.

\section{METODE PENELITIAN}

Rancangan penelitian yang digunakan dalam penelitian ini adalah analitik kuantitatif dengan desain potong lintang (cross sectional) yaitu suatu penelitian yang mempelajari dinamika korelasi antara faktor-fakor risiko dengan efek, dengan cara pendekatan observasi atau pengumpulan data sekaligus pada satu waktu.

Lokasi penelitian ini dilakukan di Kabupaten Kepahiang, Provinsi Bengkulu, yang dilaksanakan pada bulan Oktober 2021. Populasi dalam penelitian ini adalah seluruh ibu hamil di Kabupaten Kepahiang tahun 2021 yang usia kurang dari 20 tahun sebanyak 126. Pengambilan sampel dilakukan dengan cara tidak acak atau metode non-probability yaitu purposive sampling dengan menggunakan rumus teori Lemesshow dari sebanyak 126 populasi.

Metode yang digunakan untuk menentukan jumlah responden minimal dapat menggunakan Rumus Lemeshow tingkat kepercayaan 95\%, Jadi total sampel dalam penelitian ini berjumlah 92 responden. Sebelum melakukan pengumpulan data, peneliti meminta persetujuan responden untuk menjadi subjek penelitian dengan menandatangani pernyataan persetujuan bersedia menjadi subjek penelitian lalu data dianalisis menggunakan uji statistik chi square.

\section{HASIL PENELITIAN Analisis Univariat}

Tabel. 1

Distribusi Frekueunsi Sikap Respoden terhadap Kejadian Anemia Ibu Hamil

\begin{tabular}{lccc}
\hline & Sikap & Frekuensi & Persentase (\%) \\
\hline Negatif & 45 & 44,6 \\
Positif & 56 & 55,4 \\
\hline
\end{tabular}


Berdasarkan tabel 1 menunjukkan distribusi frekuensi responden berdasarkan sikap responden terhadap kejadian anemia di Kabupaten Kepahiang dimana terdapat sebagian besar responden atau sebanyak 56 orang $(55,4 \%)$ memiliki sikap positif.

Tabel. 2

Distribusi Frekuensi Keteraturan Konsumsi TTD Respoden terhadap kejadian Anemia Ibu Hamil

\begin{tabular}{lcc}
\hline \multicolumn{1}{c}{ Konsumsi TTD } & Frekuensi & Persentase (\%) \\
\hline Tidak Teratur & 61 & 60,4 \\
\hline Teratur & 40 & 39,6 \\
\hline
\end{tabular}

Berdasarkan tabel 2 menunjukkan distribusi frekuensi responden dalam mengkonsumsi tablet tambah darah, dimana dari 101 orang responden sebagian besar atau sebanyak 61 orang $(60,4 \%)$ memiliki perilaku tidak teratur dalam mengkonsumsi tablet tambah darah.

Tabel. 3

Distribusi Frekueunsi

Kejadian Anemia ibu Hamil

\begin{tabular}{lcc}
\hline \multicolumn{1}{c}{ Status Ekonomi } & Frekuensi & Persentase (\%) \\
\hline Anemia & 82 & 81,2 \\
\hline Tidak Anemia & 19 & 18,8 \\
\hline
\end{tabular}

Berdasarkan tabel 3 menunjukkan kejadian anemia, hasil penelitian menunjukkan bahwa dari 101 responden dalam penelitian berdasarkan hasil pengukuran kadar $\mathrm{Hb}$ menunjukkan hampir seluruhnya atau sebanyak 82 orang $(81,2 \%)$ mengalami anemia.

\section{Analisis Bivariat}

Tabel. 4

Hubungan Keteraturan Konsumsi TTD

terhadap Kejadian Anemia Ibu Hamil

\begin{tabular}{|c|c|c|c|c|c|c|c|c|}
\hline \multirow{3}{*}{$\begin{array}{c}\text { Konsumsi Tablet } \\
\text { Tambah Darah }\end{array}$} & \multicolumn{4}{|c|}{ Kejadian Anemia } & \multirow{3}{*}{ Total } & \multirow{3}{*}{$\%$} & \multirow{3}{*}{$P$} & \multirow{3}{*}{$O R$} \\
\hline & \multicolumn{2}{|c|}{ Anemia } & \multicolumn{2}{|c|}{ Tidak Anemia } & & & & \\
\hline & $\mathrm{N}$ & $\%$ & $\mathrm{~N}$ & $\%$ & & & & \\
\hline Tidak Teratur & 60 & 98,4 & 1 & 1,6 & 61 & 100 & & \\
\hline Teratur & 22 & 55,0 & 18 & 45,0 & 40 & 100 & 0,000 & 49,1 \\
\hline Total & 82 & 81,2 & 19 & 22,6 & 101 & 100 & & \\
\hline
\end{tabular}

Berdasarkan tabel 4 menunjukkan dari 61 orang responden yang tidak teratur mengkonsumsi tablet tambah darah hampir keseluruhan atau sebanyak 60 orang responden $(98,4 \%)$ mengalami kejadian anemia, sedangkan dari 40 orang responden yang teratur mengkonsumsi tablet tambah darah sebagian besar atau sebanyak 22 orang $(55 \%)$ mengalami kejadian anemia.

Hasil uji statistik dengan uji chi-square menunjukkan p-value sebesar $0,000(\mathrm{p}<$ 0,05 ) dengan OR sebesar 49,1 sehingga ada hubungan antara keteraturan mengkonsumsi tablet tambah darah dengan kejadian anemia di Kabupaten Kepahiang dengan peluang 
terjadinya anemia pada ibu hamil sebesar 49,1 kali beresiko responden yang tidak teratur mengkonsumsi tablet tambah darah dibanding dengan responden yang teratur mengkonsumsi tablet tambah darah.

\section{PEMBAHASAN}

Hasil penelitian menujukkan bahwa responden dengan sikap negatif hampir keseluruhan mengalami anemia, sedangkan sikap kategori positif sebagian besar mengalami kejadian anemia. Penelitian ini sejalan dengan penelitian Susilowati et al., (2021) dimana responden dengan sikap positif cenderung lebih banyak mengalami anemia $(59,5 \%)$ dibandingkan dengan responden dengan sikap positif tentang anemia pada kehamilan.

Fenomena yang menarik dari hasil penelitian ini adalah adanya responden yang memiliki sikap positif namun mengalami kejadian anemia. Berdasarkan asumsi peneliti fenomena ini disebabkan karena sikap hanya merupakan tanggapan atau reaksi sesorang terhadap objek tertentu dalam hal ini kejadian anemia pada kehamilan, namun belum menyatakan tindakan yang nyata.

Beberapa faktor yang dapat mempengaruhi sikap seseorang, misalnya pengalaman pribadi. Apa yang telah dan sedang kita alami akan ikut membentuk dan mempengaruhi penghayatan kita terhadap stimulus sosial. Tanggapan akan menjadi salah satu dasar terbentuknya sikap. Untuk dapat mempunyai tanggapan dan penghayatan, seseorang harus mempunyai pengalaman yang berkaitan dengan objek psikologis yang akan membentuk sikap positif dan sikap negatif. Pembentukan tanggapan terhadap obyek merupakan proses kompleks dalam diri individu yang melibatkan individu yang bersangkutan, situasi di mana tanggapan itu terbentuk, dan ciri-ciri obyektif yang dimiliki oleh stimulus. Untuk dapat menjadi dasar pembentukan sikap, pengalaman pribadi tersebut terjadi dalam situasi yang melibatkan faktor emosional.

Dalam penelitian ini hampir seluruh responden $(77,2 \%)$ adalah ibu hamil dengan paritas nulipara dan primipara, yang artinya responden baru pertama kali mengalami kehamilan dan baru sekali mengalami kehamilan sehingga belum memiliki pengalaman yang cukup sehingga dapat lebih menguatkan atas sikap positif yang dimilikinya terkait dengan anemia pada saat kehamilan.

\section{Keteraturan Mengkonsumsi Tablet Tambah Darah}

Hasil penelitian menunjukkan jumlah responden yang teratur mengkonsumsi tablet tambah darah sebanyak 61 orang sedangkan yang tidak teratur mengkonsumsi sebanyak 40 orang. Dari 61 orang responden yang tidak teratur mengkonsumsi tablet tambah darah tersebut hampir keseluruhan atau sebanyak 60 orang responden mengalami kejadian anemia sedangkan dari 40 orang responden yang teratur mengkonsumsi tablet tambah darah sebagian besar atau sebanyak 22 orang mengalami kejadian anemia.

Hasil penelitian ini menunjukkan pada responden yang teratur mengkonsumsi tablet tambah darah hampir seluruhnya tidak mengalami anemia, hal ini menunjukkan dengan teratur mengkonsumsi tablet tambah darah pada waktu hamil kan membantu dalam mencegah kejadian anemia. Hasil penelitian yang dilakukan oleh Anggraini et al., (2018) menyebutkan bahwa semakin tinggi tingkat kepatuhan ibu hamil dalam mengonsumsi tablet Fe maka semakin tinggi pula ibu hamil untuk tidak tekena anemia pada masa kehamilan. 
Hasil penelitian ini sejalan dengan penelitian Dolang (2020) dimana untuk kepatuhan mengonsumsi tablet $\mathrm{Fe}$ menunjukkan bahwa sebagian besar responden patuh dalam mengonsumsi tablet $\mathrm{Fe}(52,2 \%)$ dan dari 115 responden terdapat 51,3\% yang mengalami anemia.

Konsumsi tablet Fe yang berisi zat besi dibutuhkan ibu hamil untuk membantu meningkatkan kadar hemoglobin dan jumlah sel darah merah yang akan membantu dalam menanggulangi anemia selama masa kehamilan. Untuk membantu meningkatkan penyerapan dan cadangan besi diperlukan Fe, jika kebutuhan Fe tidak terpenuhi dari makanan, maka dapat ditambah dengan tablet tambah darah (tablet Fe). Pemberian tablet tambah darah dalam jangka waktu panjang dan dosis yang minimal lebih baik dibandingkan dengan dengan dosis yang besar namun sekali pemberian. Dengan pemberian suplemen tablet zat besi (Fe) pada ibu hamil dapat meningkatkan kadar zat besi $(\mathrm{Fe})$ dalam jangka waktu yang pendek pada ibu hamil. Hasil penelitian yang dilakukan oleh Astriana (2017) menunjukkan bahwa Dari 277 responden yang mengalami kejadian anemia pada ibu hamil sebanyak 118 responden $(42,6 \%)$ dan 159 responden (57, 4\%) yang tidak mengalami kejadian anemia pada ibu hamil, paritas beresiko sebanyak 226 responden $(81,6 \%)$ dan paritas tidak beresiko sebanyak 51 responden (18, 4\%), umur beresiko sebanyak 199 responden $(71,8 \%)$ dan umur tidak beresiko sebanyak 78 responden $(28,2 \%)$. Analisa statistik menunjukkan adanya korelasi antara kejadian anemia pada ibu hamil dengan paritas ( $p$ value 0,023$)$ dan usia ( $p$ value 0,028 ).

Dalam penelitian ini responden yang teratur dalam mengkonsumsi tablet $\mathrm{Fe}$ akan tetapi mengalami anemia hal ini dimungkinkan karena ketidaktepatan dalam dosis dan ketentuan dalam konsumsi. Hal ini sejalan dengan pendapat Izzati et al., (2021) yang menyatakan suplementasi tablet $\mathrm{Fe}$ dalam penanggulangan anemia telah dikaji secara ilmiah efektivitasnya jika dilaksanakan sesuai dosis dan ketentuan.

Tetapi program pemberian tablet Fe pada ibu hamil kurang menunjukkan hasil yang signifikan pada penanggulangan anemia ibu hamil. Hal ini disesbabkan karena dua hal yaitu kepatuhan konsumsi tablet $\mathrm{Fe}$ yang rendah dan status kadar hemoglobin pada Wanita Usia Subur (WUS) sebelum hamil yang rendah. Ketidakpatuhan ibu hamil dalam mengonsumsi tablet Fe disebabkan karena beberapa faktor seperti adanya efek samping, lupa dan tidak rutin kontrol. Pada saat pelaksanaan ANC ibu hmil akan dianjurkan untuk mengkonsumsi secara teratur tablet zat besi minimal 90 tablet selama kehamilan (Purwandari et al., 2016).

\section{Kejadian Anemia pada Masa Kehamilan}

Hasil penelitian menunjukkan kejadian anemia dari 101 responden berdasarkan hasil pengukuran kadar $\mathrm{Hb}$ hampir seluruhnya atau sebanyak 82 orang mengalami anemia. Anemia adalah suatu keadaan dimana kada Hemoglobin $(\mathrm{Hb})$ dalam darah lebih rendah dari normal untuk kelompok orang menurut umur dan jenis kelamin, pada wanita usia remaja hemoglobin normal adalah 12-15 g/dl, dan pada pria remaja hemoglobin 13$17 \mathrm{~g} / \mathrm{dl}$ (Ramadhaniati et al., 2020). Faktor - faktor yang mempengaruhi kejadian anemia pada ibu hamil yaitu faktor dasar, faktor langsung, dan tidak langsung.

Berdasarkan hasil penelitian yang telah dilakukan oleh Ginting et al., (2021) umur yang berisiko, paritas terlalu banyak menjadi faktor yang berhubungan dengan kejadian anemi pada ibu hamil. Berdasarkan penelitian Sulfianti (2021) juga menyatakan bahwa umur ibu berhubungan dengan kejadian anemia. Hasil penelitian Irwan \& Rahmat (2018) juga menyatakan terdapat hubungan umur ibu dengan kejadian ibu hamil. 


\section{Hubungan Sikap dengan Kejadian Anemia}

Analisis dengan tabulasi silang antara variabel sikap dengan kejadian anemia menunjukkan dimana dari 45 orang responden dengan sikap negatif hampir keseluruhan responden atau sebanyak 41 orang $(91,1 \%)$ mengalami kejadian anemia, jumlah ini cenderung lebih banyak jika dibanding dengan responden dengan sikap kategori positif yaitu sebesar $73,2 \%$.

Dari uji statistik chi square diperoleh $p$ value sebesar $0,022(\mathrm{p}<0,05)$ dengan nilai Odds Ratio (OR) 3,750 sehingga Ho ditolak dan H1 diterima yang artinya ada hubungan antara sikap dengan kejadian dengan anemia dengan peluang terjadinya anemia pada ibu hamil sebesar 3,750 kali beresiko responden dengan sikap negatif dibanding dengan responden dengan sikap positif.

Penelitian ini sejalan dengan penelitian Putri (2019) dalam penelitiannya menyatakan hubungan sikap ibu hamil tentang terjadinya anemia dengan konsumsi tablet Fe, diketahui bahwa nilai probabilitasnya $(0,000)<0,05$, Hasil analisis ini memenuhi kriteria persyaratan hipotesis ada hubungan, sehingga dapat disimpulkan bahwa sikap ibu hamil mempunyai hubungan yang signifikan terhadap terjadinya anemia.

Dalam penelitian ini sikap responden didukung dengan pengetahuan yang baik, terdapat responden yang masih memiliki sikap negatif tentang anemia kehamilan, hal ini disebabkan karena sebagian besar responden $(61,4 \%)$ masih memiliki pengetahuan yang tidak baik. Sikap merupakan konsep paling penting dalam psikologi sosial yang membahas unsur sikap baik sebagai individu maupun kelompok. Melalui sikap kita memahami proses kesadaran yang menentukan tindakan nyata dan yang tindakan yang mungkin dilakukan individu dalam kehidupan sosialnya. Sikap adalah suatu predisposisi yang dipelajari untuk merespon secara konsisten, baik positif maupun negatif terhadap suatu objek.

Dalam penelitian ini sikap yang ditunjukan oleh responden masih termasuk dalam komponen afektif dimana sikap yang ditunjukan berkaitan dengan emosi atau perasaan responden terhadap anemia kehamilan.

\section{Hubungan Ketaraturan ANC dengan Kejadian Anemia}

Hasil anaslias tabulasi silang antara variabel keteraturan ANC dengan kejadian anemia menunjukkan responden yang tidak teratur melakukan ANC hampir keseluruhan $87 \%$ mengalami kejadian anemia cenderung lebih banyak dibandingkan dengan responden yang teratur dalam melakukan ANC walaupun persentase terjadinya anemia masih cukup banyak yaitu (79,5\%). Hasil uji statistik dengan menggunakan uji chi square diperoleh $p$ value sebesar 0,551 ( $>0,05)$ yang artinya tidak ada hubungan antara keteraturan ANC dengan kejadian dengan anemia di Kabupaten Kepahiang.

Hasil penelitian ini berbeda dengan penelitian yang dilakukan oleh Juliarti (2017) dengan hasil penelitian terdapat hubungan antara pengetahuan ibu hamil dan kunjungan ANC dengan dengan kejadian anemia di Puskesmas Melur, dengan $p$-value sebesar 0,001.

Pelayanan antenatal care merupakan pelayanan kesehatan yang diberikan kepada ibu selama kehamilannya sesuai dengan standar pelayanan antenatal seperti yang ditetapkan dalam buku pedoman pelayanan antenatal terpadu bagi petugas kesehatan. Pelayanan antenatal yang lengkap mencakup banyak hal seperti anamnesis, pemeriksaan fisik umum dan kebidanan, pemeriksaan laboratorium sesuai dengan indikasi serta intervensi dasar dan kasus (sesuai resiko yang ada). 
Responden yang melakukan kunjungan ANC secara teratur akan tetapi tetap mengalami anemia berdasarkan asumsi penulis dapat disebabkan karena kunjungan ANC yang dilakukan oleh respoden tidak sesuai dengan standar minimal, diantaranya tidak melakukan kunjungan ANC diawal trisemester kehamilan. Hal ini dapat menyebabkan responden tidak mengetahui resiko yang dapat terjadi pada kehamilannya. Menurut SDKI, 2017 terdapat sebanyak 8 dari 10 ibu hamil yang mengawali pemeriksaan kehamilan pada trisemester I, atau pada saat umur kanding kurang dari 4 bulan.

\section{SIMPULAN}

Berdasarkan hasil penelitian dan pembahasan serta disesuaikan dengan tujuan penelitian, maka ditarik kesimpulan yaitu ada hubungan antara prilaku mengkonsumsi tablet tambah darah dengan kejadian anemia pada ibu hamil.

\section{SARAN}

\section{Bagi Petugas Kesehatan}

Perlu meningkatkan upaya promosi kesehatan kepada ibu hamil mengenai tablet besi, anemia, dengan mengadakan penyuluhan, pemberian informasi melalui berbagai media seperti pamphlet, pemasangan spanduk, stiker dan kemunikasi lainnya.

\section{Bagi Ibu Hamil}

Perlu meningkatkan pengetahuan dan sikapnya tentang keteraturan mengkonsumsi tablet Fe melalui berbagai media informasi dan meningkatkan kunjungan pemeriksaan kehamilan.

\section{Bagi Peneliti Selanjutnya}

Perlu dilakukan penelitian lanjutan dengan menggunakan variabel-variabel lain yang berhubungan keteraturan mengkonsumsi tablet Fe.

\section{DAFTAR PUSTAKA}

Andini, A. (2020). Angka Kematian Ibu di Indonesia Masih Jauh dari Target SDGs. https://lokadata.id/artikel/angka-kematian-ibu-di-indonesia-masih-jauh-dari-targetsdgs

Anggraini, D. D., Purnomo, W., \& Trijanto, B. (2018). Interaksi Ibu Hamil dengan Tenaga Kesehatan dan Pengaruhnya terhadap Kepatuhan Ibu Hamil Mengkonsumsi Tablet Besi (Fe) dan Anemia di Puskesmas Kota Wilayah Selatan Kota Kediri. Buletin Penelitian Sistem Kesehatan, 21(2), 82-89. https://ejournal2.litbang.kemkes.go.id/index.php/hsr/article/view/346

Astriana, W. (2017). Kejadian Anemia pada Ibu Hamil Ditinjau dari Paritas dan Usia. Jurnal Aisyah: Jurnal Ilmu Kesehatan, 2(2), 123-130. https://doi.org/10.30604/jika.v2i2.57

Dinkes Kepahiang. (2019). Dinas Kesehatan Kepahiang Arsip. https://kepahiang.progres.id/read/dinas-kesehatan-kepahiang

Dinkes Provinsi Bengkulu. (2019). Profil Kesehatan Provinsi Bengkulu 2018 Dinas Kesehatan Provinsi Bengkulu Tahun 2019. 211

Dolang, M. W. (2020). Hubungan Kepatuhan Mengonsumsi Tablet Fe dan Keteraturan Kunjungan ANC dengan Kejadian Anemia pada Ibu Hamil. Jurnal Keperawatan Muhammadiyah, 5(1), 179-184. https://doi.org/10.30651/jkm.v5i1.4189 
Ginting, S. S. T., Damanik, L. P., Sembiring, A., Imarina, I., \& Mardiah, M. (2021). Hubungan Karakteristik Ibu dengan Kejadian Anemia pada Ibu Hamil di Wilayah Kerja Puskesmas Sei Bejangkar Kabupaten Batubara Tahun 2020. Excellent Midwifery Journal, 4(2), 107-117. https://jurnal.mitrahusada.ac.id/index.php/emj/article/view/178/135

Irwan, H., \& Rahmat, B. (2018). Hubungan Umur dan Paritas terhadap Kejadian Anemia PADA Ibu Hamil di RSKDIA Siti Fatimah Makassar Tahun 2018. Jurnal Kesehatan Delima Pelamonia, 2(1), 71-76. https://doi.org/10.37337/jkdp.v2i1.64

Izzati, A. I., Tamtomo, D., \& Rahardjo, S. S. (2021). Hubungan Tingkat Kepatuhan Konsumsi Tablet Fe dengan Kejadian Anemia Ibu Hamil di Puskesmas Margasari. In Prosiding Seminar Nasional Kesehatan Masyarakat Universitas Muhammadiyah Surakarta 2021. https://publikasiilmiah.ums.ac.id/handle/11617/12507

Juliarti, W. (2017). Hubungan Faktor Penyebab dengan Kejadian Anemia di Puskesmas Melur. Jurnal Penelitian Kesehatan Suara Forikes, VII(1), 25-28. https://web.archive.org/web/20180422182638id_/http://forikesejournal.com/index.php/SF/article/viewFile/81/sf8106

Kemenkes RI, (2020). Profil Kesehatan Indonesia Tahun 2020. https://www.kemkes.go.id/downloads/resources/download/pusdatin/profilkesehatan-indonesia/Profil-Kesehatan-Indonesia-Tahun-2020.pdf

Mairita, M., Syamsul, A., \& Nur, A. F. (2018). Hubungan Status Gizi dan Pola Haid dengan Kejadian Anemia pada Remaja di Wilayah Kabupaten Banjar Tahun 2017. Universitas Islam Kalimantan Muhammad Arsyad Al Banjari. http://eprints.uniskabjm.ac.id/2674/1/artikel nurhayati \%281\%29-dikonversi.pdf

Musni, M. (2019). Faktor yang Berhubungan dengan Kejadian Anemia pada Ibu Hamil di Puskesmas Watampone. Nursing Inside Community, 1(1), 1-6. https://doi.org/10.35892/nic.v1i1.3

Purwandari, A., Lumy, F., \& Polak, F. (2016). Faktor-Faktor yang Berhubungan dengan Kejadian Anemia. Jurnal Ilmiah Bidan, 4(1), 62-68. http://bit.ly/Anemia34

Putri, D. K. (2019). Hubungan Pengetahuan dan Sikap Ibu Hamil Trimester III dalam Konsumsi Tablet Fe dengan Terjadinya Anemia di BPM Mardiani Ilyas Aceh Tahun 2018. Jurnal Midwifery Update (MU), $1(1), 47$. https://doi.org/10.32807/jmu.v1i1.40

Ramadhaniati, F., Masrul, M., \& Ali, H. (2020). Analisis Implementasi Program Pelayanan Antenatal Terpadu pada Ibu Hamil dengan Kekurangan Energi Kronis dan Anemia di Kota Padang. Jurnal Kesehatan Andalas, 8(4), 89-99. https://doi.org/10.25077/jka.v8i4.1123

Ramdhani, H. C., \& Ichwanuddin, I. (2020). Gambaran Pengetahuan Sikap dan Kepatuhan Konsumsi Tablet Tambah Darah (TTD) pada Remaja Putri di SMPN 1 Ggesik Kabupaten Cirebon. Politeknik Kesehatan Kemenkes Bandung. http://repo.poltekkesbandung.ac.id/1198/

Riskesdas. (2018). Hasil Utama Riset Kesehatan Dasar. Kementrian Kesehatan Republik Indonesia, 1-100. https://doi.org/https://doi.org/10.1088/1751-8113/44/8/085201

Sulfianti, S. (2021). Faktor-Faktor yang Mempengaruhi Anemia pada Ibu Hamil di UPT Puskesmas Ajangale. Bina Generasi: Jurnal Kesehatan, 13(1), 39-49. https://doi.org/10.35907/bgjk.v13i1.193 
Susilowati, L., Sagita, Y. D., \& Veronica, S. Y. (2021). Hubungan Pengetahuan dan sikap ibu Hamil dengan Kejadian Anemia di Wilayah Kerja UPTD Puskesmas Ngarip Kabupaten Tanggamus Tahun 2021. Jurnal Maternitas Aisyah (Jaman Aisyah), 2(2), 154-165. http://journal.aisyahuniversity.ac.id/index.php/Jaman/article/view/ibuhamilngarip 